\title{
PENGELOLAAN PEMBELAJARAN DI SEKOLAH MENENGAH PERTAMA AL-FAQIH SUMBER NYAMPLONG KOWEL PAMEKASAN
}

\author{
Badrud Tamam, Zainol Hasan, dan Hilmi Qosim Mubah ${ }^{1}$ \\ Fakultas Tarbiyah IAIN Madura \\ badruttamam@gmail.com,pendidikanagamaislam@gmail.com dan \\ hilmiqosimmubah@iainmadura.ac.id
}

\begin{abstract}
Abstrak
SMP Al-Faqih Somber Nyamplong Kowel Pamekasan merupakan salah satu lembaga tingkat menengah yang secara langsung berada di bawah naungan pondok pesantren yang ada di kecamatan Pamekasan. Lembaga tersebut pada saat ini sedang melakukan upaya-upaya peningkatan mutu pembelajaran seperti melakukan perencanaan pembelajaran yang dituangkan dalam Rencana Program Pembelajaran (RPP), Hasil penelitian menunjukkan bahwa: Pertama, 1) Guru melakukan perencanaan terlebih dahulu dengan menetapkan sasaran tujuan pengajaran yang jelas dan konkret, 2) Guru melakukan pengorganisasian strategi belajar dengan menetapkan jenis metode, media, sumber belajar dan fasilitas belajar mengajar. Kedua, 1) Siswa lebih aktif dan kegiatan pembelajaran lebih menyenangkan, 2) Siswa mampu meningkatkan pengetahuannya terhadap materi yang sudah dan yang akan di sampaikan guru. Ketiga, 1) Faktor pendukungnya yaitu; a) Kegiatan pembelajaran lebih efektif dan menyenangkan, b) Siswa memiliki minat dan motivasi untuk belajar yang lebih baik. 2) Faktor penghambat strategi pengelolaan pembelajaran di SMP Al-Faqih yaitu; a) Faktor lingkungan yang ada dibawah naungan pondok pesantren, b) Minimnya sarana dan prasarana yang memadai.
\end{abstract}

Kata kunci: : Pengelolaan, Pembelajaran, aktif

\begin{abstract}
SMP Al-Faqih Nyamplong Kowel Pamekasan is one of the middle-level institutions which is directly under the auspices of the Islamic boarding schools in the Pamekasan sub-district. The institute is currently making efforts to improve the quality of learning such as conducting learning planning as outlined in the Learning Program Plan (RPP), the results of the study show that: First, 1) The teacher does the planning first by setting clear and concrete objectives, 2) The teacher organizes learning strategies by determining the types of methods, media, learning resources and teaching and learning facilities. Second, 1) Students are more active and learning activities are more fun, 2) Students can increase their knowledge of the material that has been and will be conveyed by the teacher. Third, 1) The supporting factors are; a) Learning activities are more effective and fun, b) Students have an interest and motivation to learn better. 2) Inhibiting factors for learning management strategies at Al-Faqih Middle School, namely; a) Environmental factors that are under the auspices of Islamic boarding schools, $b$ ) The lack of adequate facilities and infrastructure.
\end{abstract}

Keywords: management, learning, active

\footnotetext{
${ }^{1}$ Penulis korespondensi
} 


\section{PENDAHULUAN}

Kesuksesan suatu pendidikan akan terjadi apabila terdapat interaksi antar guru dengan siswa. Guru merupakan pendidik yang menjadi pemimpin dalam pembelajaran, mereka menjadi penentu dalam proses pembelajaran, peran kepemimpinan tersebut akan tercermin dalam pelaksanaan fungsi dan tugas guru. Hal ini menunjukkan bahwa kinerja guru menjadi faktor yang menentukan untuk mencapai mutu pembelajaran/pendidikan yang berimplikasi pada output yang berkualitas pada pendidikan setelah menyelesaikan pendidikan. $^{2}$

Reformasi pada bidang pendidikan bukan hanya dengan merubah kurikulum, baik yang meliputi struktur maupun prosedur dalam perumusannya. Pembaruan kurikulum menjadi lebih berarti apabila disertai dengan perubahan praktik pembelajaran di dalam kelas maupun di luarnya. Adapun indikator pembaruan kurikulum dibuktikan dengan adanya perubahan pola program pembelajaran, media pendidikan yang dipilih, pemilihan pola penilaian sebagai penentu hasil pembelajarn. Kemampuan dan kompetensi guru yang akan menerapkan kurikulum mempengaruhi tingkat keberhasilan dalam implementasi kurikulum, terutama pada bidang yang berkaitan dengan kognitif dan kemampuan serta tugas yang dibebankan kepadanya. ${ }^{3}$

Pengelolaan merupakan hasil proses berpikir dan tindakan yang mendalam; hasil dari proses pengkajian dan mungkin penyeleksian dari berbagai alternatif yang dianggap lebih memiliki nilai efektifitas dan efesiensi. Pengelolaan adalah awal dari dari semua proses suatu pelaksanaan kegiatan yang bersifat rasional. Dengan demikian, maka seoarang guru harus dapat memvisualisasikan arah dan tujuan yang harus dicapai serta bagaimana cara untuk mencapai tujuan tersebut melalui pemanfaatan berbagai potensi yang ada agar proses pencapaian tujuan lebih efektif dan efisien. ${ }^{4}$

Pengelolaan pembelajaran merupakan suatu proses pengaturan dan kerja sama antara guru dan siswa dalam memanfaatkan segala potensi dan sumber yang ada baik potensi yang bersumber dari dalam diri siswa itu sendiri seperti minat, bakat dan kemampuan dasar yang dimiliki termasuk gaya belajar maupun potensi yang ada di luar diri siswa seperti lingkungan, sarana dan sumber belajar sebagai upaya untuk mencapai tujuan belajar. Menurut Muhibbin Syah bahwa proses hasil belajar mengajar dipengaruhi diantaranya faktor lingkungan, faktor instrumental (kurikulum, program, sarana, guru), faktor fisiologis dan faktor psikologis. ${ }^{5}$

Pada saat ini SMP Al-Faqih Sumber Nyamplong Kowel Pamekasan sedang melakukan upaya-upaya peningkatan mutu pembelajaran seperti adanya tambahan jam pelajaran bagi siswa berprestasi, melakukan perencanaan pembelajaran yang dituangkan dalam Rencana Program Pembelajaran (RPP), penggunaan metode dan media pembelajaran yang sesuai dengan pokok bahasan materi dan menyampaikan tujuan pembelajaran yang harus dicapai oleh siswa dalam kegiatan pembelajaran. Meskipun

2 Engkay Karwate, Pengaruh Kemampuan Manajerial Kepla Sekolah dan Faktor Yang Mempengaruhi Motivasi Kerja Terhadap Kinerja Guru SLB di Kabupaten Subang, Jurnal Penelitian Pendidikan, Vol,02, No, 01, Tahun 2010, 77.

3 Abdul Majid, Perencanaan Pembelajaran Mengembangkan Standar Kompetensi Guru (Bandung: RemajaRosdakarya, 2013), 3.

4 Wina Sanjaya, Perencanaan dan Desain Sistem Pembelajaran (Jakarta: Kencana Prenada Media Group, 2012), 25.

5 Muhibbin Syah, Psikologi Belajar (Jakarta: Renika Cipta, 2011), 176. 
dalam beberapa upaya yang dilakukan mengalami peningkatan hasil dan proses kegiatan pembelajaran, akan tetapi harapan dan ekspektasi tidak sesuai dengan kenyataannya, karena masih adanya kendala-kendala yang dijumpai, sehingga dalam kegiatan pengelolaan pembelajaran kurang optimal. ${ }^{6}$

Pengelolaan pembelajaran akan efektif apabila upaya yang dilakukan sesuai dengan situasi dan kondisi sekolah, artinya pengajaran yang secara serentak memberikan peluang pencapaian tujuan instruksional mata pelajaran dan tujuan pendidikan lainnya. Dengan demikian keterampilan proses belajar mengajar perlu diketahui bahwa setiap keputusan dan tindakan guru dalam rangka kegiatan belajar mengajar akan membawa berbagai efek kepada siswa, seperti motivasi dan prestasi belajar siswa. Oleh karena itu pengelolaan pembelajaran sangat penting.

Diterapkannya pengelolaan pembelajaran bermuara pada meningkatnya motivasi dan hasil belajar siswa, hal tersebut dapat terwujud jika guru mampu melakukan pengelolaan pembelajaran sesuai dengan situasi dan kondisi.

Berdasarkan uraian konteks penelitian di atas, maka peneliti tertarik untuk melakukan penelitian lebih lanjut dengan mengangkat judul "Pengelolaan Pembelajaran di SMP Al-Faqih Sumber Nyamplong Kowel Pamekasan”.

\section{METODE PENELITIAN}

Penelitian ini menggunakan pendekatan kualitatif dan jenisnya diskriptif karena data yang dikumpulkan adalah berupa kata-kata, gambar-gambar, dan bukan angkaangka. Laporan penelitian akan berisi kutipan-kutipan data untuk memberi gambaran penyajian laporan tersebut. Data tersebut kemungkinan berasal dari naskah wawancara, catatan lapangan, foto, catatan atau memo. ${ }^{7}$

Penelitian ini menggunakan pendekatan kualitatif karena bertujuan untuk menyajikan dunia sosial, dan perspektifnya di dalam dunia, dari segi konsep, perilaku, persepsi dan persoalan tentang manusia yang diteliti. Dengan menggunakan wawancara, observasi dan dokumentasi sebagai teknik pengumpulan data.

Dalam penelitian ini yang menjadi sumber data adalah kepala sekolah, guru dan siswa SMP Al-Faqih Sumber Nyamplong Kowel Pamekasan dengan prosedur pengumpulan data melalui wawancara, observasi dan dokumentasi yang bersifat penguat atau pembuktian dari data yang diperoleh berdasarkan pernyataan subyek penelitian tersebut.

Dalam penelitian ini, langkah-langkah yang ditempuh peneliti untuk menganalisa data setelah terkumpul adalah: a) Reduksi data. yaitu peneliti mengidentifikasi data yang diperoleh yang berkaitan dengan fokus dan masalah penelitian. Dalam melakukan reduksi data ini terdiri atas proses pemilihan, pemusatan perhatian pada penyederhanaan, pengabstrakan, dan transformasi data kasar. b) Penyajian data, yakni peneliti melakukan pengolahan data yang diperoleh serta menafsirkan data yang lebih luas dari jawaban hasil penelitian dan menggabungkannya dengan teori-teori yang dihasilkan. c) Penarikan kesimpulan, yakni menemukan kesimpulan yang akurat, sehingga diverifikasi untuk merumuskan kesimpulan yang bersifat pasti.

\footnotetext{
6 Mohammad Musleh Suaidi, Kepala SMP Al-Faqih Sumber Nyamplong Kowel Pamekasan, Wawancara Langsung, Tanggal 20 Agustus 2018.

7 Lexy J. Moleong, Metodologi Penelitian Kualitatif(Bandung: PT. Remaja Rosdakarya 2014), . 11.
} 
Untuk mengetahui apakah data-data yang diperoleh dari penelitian ini absah atau sesuai dengan tujuan penelitian yang diharapkan, maka peneliti berusaha mengecek secara cermat agar penelitian ini dilakukan tidak terkesan sia-sia atau simbol semata. Oleh karena dalam pengecekan keabsahan data ini dilakukan dengan cara: a) perpanjangan keikutsertaan merupakan suatu hal yang sangat menentukan dalam pengumpulan data. Keikutsertaan tersebut tidak hanya dilakukan dalam waktu yang singkat. Tetapi memerlukan perpanjangan keikutsertaan peneliti, dan b) triangulasi adalah teknik pemeriksaan keabsahan data yang memanfaatkan suatu yang lain di luar data ini sebagai pembanding.

\section{HASIL DAN PEMBAHASAN}

\section{Pengelolaan Pembelajaran di SMP Al-Faqih Sumber Nyamplong Kowel Pamekasan}

Dalam kegiatan belajar mengajar sasaran yang dituju harus jelas dan terarah supaya tujuan pengajaran yang jelas dan konkret akan memudahkan peserta didik memahami materi pelajaran. Sebagaimana kutipan wawancara berikut ini;

"Penetapan tujuan pengajaran yang jelas sangat penting untuk disampaikan kepada siswa, karena dengan begitu lebih mempermudah siswa dalam memahami materi yang harus dikuasai. Selain itu kegiatan belajar mengajar akan lebih terarah sesuai dengan tujuan tersebut, seperti menetapkan dan membahas materi-materi pokok yang harus disampaikan kepada siswa, sehingga siswa lebih mudah dalam mencapai tujuan pengajaran". 8

Berdasar hasil pengamatan, guru di SMP Al-Faqih Sumber Nyamplong Pamekasan melakukan Tanya jawab tentang materi sebelumnya yang kemudian dilanjutkan dengan menyampaikan tujuan pembelajaran yang harus dicapai oleh siswa dalam kegiatan belajar mengajar tersebut kepada siswanya. Tujuan pembelajaran merupakan sasaran yang harus dicapai oleh siswa dan didesain sedemikian rupa oleh guru agar lebih mudah dicapainya oleh siswa. ${ }^{9}$

Sedangkan mengenai strategi pengorganisasian pembelajaran memiliki peranan penting dalam kegiatan pembelajaran, khususnya dalam menyususn skema kegiatan atau alur kegiatan belajar mengajar. Untuk itu guru SMP Al-Faqih melakukan pengorganisasian pembelajaran agar kegiatan belajar mengajar lebih optimal. Sebagaimana kutipan wawancara berikut ini;

"Kegiatan pengorganisasian pembelajaran perlu dilakukan oleh guru, agar kegiatan pembelajaran lebih terstruktur, tertata rapi dan sesuai dengan harapan.

Dalam kegiatan pengorganisasian pembelajaran ini guru berusaha menyesuaikan fasilitas atau sarana sekolah dengan materi pelajaran, guru menetapkan metode dan media yang sesuai dengan materi dan guru berupaya menyediakan sumbersumber belajar yang dapat mendukung kegiatan pembelajaran yang efektif". ${ }^{10}$

Untuk menambah validitas data yang sudah diperoleh, peneliti mengadakan observasi ke lokasi penelitian. Mengenai penetapan sumber belajar, metode dan

8 Zainullah, Guru Mata Pelajaran SMP Al-Faqih Sumber Nyamplong Pamekasan, Wawancara Langsung, Tanggal 02 Oktober 2018.

9 Observasi, Tentang Penyampaian Tujuan Pembelajaran Kepada Siswa, Tanggal 05 Oktober 2018.

10 Muhammad Musleh Suaidi, Kepala SMP Al-Faqih Sumber Nyamplong Pamekasan, Wawancara Langsung, Tanggal 05 Oktober 2018. 
media pembelajaran sebagaimana yang telah dituangkan dalam Rencana Program Pembelajaran (RPP). Tahap pengorganisasian pembelajaran tersebut sebagai landasan bagi guru dalam merancang kegiatan belajar mengajar di kelas. Seperti penggunaan metode dan media pembelajaran yang sesuai dengan materi dan karakteristik peserta didik. Oleh karena itu RPP menjadi bagian yang sangat penting di SMP Al-Faqih yang dan wajib dibuat oleh guru dalam melaksanakan kegiatan belajar mengajar. ${ }^{11}$

Kegiatan belajar mengajar yang efektif adalah kegiatan belajar yang salah satunya sesuai dengan ketentuan waktu yang disediakan, sehingga tidak menggangu kegiatan belajar berikutnya. Hal itu juga menjadi perhatian bagi guru di SMP AlFaqih, karena bagaimanapun bagusnya kegiatan belajar yang dilaksanakan jika waktu tidak diatur maka akan memberikan dampak pada kegiatan pembelajar berikutnya. Sebagaimana kutipan wawancara berikut ini;

"Penentuan waktu kegiatan belajar mengajar yang efektif sangatlah penting.

Dalam penentuan waktu tersebut kami atur sebagaimana yang tertuang dalam

RPP, seperti 15 menit kegiatan awal, 60 menit kegiatan inti dan 15 menit kegiatan akhir. Selain itu kami juga terus memberikan dorongan dan motivasi kepada siswa untuk lebih aktif belajar agar Ketuntasan Kriteria Minimal (KKM) dapat dicapai oleh siswa." 12

Sedangkan berdasarkan hasil pengamatan pada saat kegiatan belajar mengajar sedang berlangsung, guru menyisihkan waktu kepada siswa untuk memberikan motivasi melalui contoh seorang figur yang sukses dalam belajar dengan harapan siswa lebih aktif dan tidak pasif dalam kegiatan belajar. ${ }^{13}$

Sedangkan untuk mengetahui kegiatan pembelajaran yang dilaksanakan efektif dan efisien, guru SMP Al-faqih berupaya melakukan evaluasi diri dengan membandingkan kegiatan pembelajar sebelumnya. Sebagaimana kutipan wawancara berikut ini;

"Kegiatan evaluasi pelaksanaan pembelajaran ini, sengaja kami lakukan untuk membandingkan kegiatan pembelajaran dengan kegiatan sebelumnya, sehingga kami memiliki solusi jika didapat hal-hal yang tidak diharapkan terjadi selama kegiatan pembelajaran berlangsung, seperti, siswa ramai pada saat kegiatan belajar berlangsung, siswa kurang paham dengan materi pelajaran, terjadinya kesalahan teknis dengan media yang digunakan dan juga penggunaan metode pembelajaran yang lebih efektif.,"14

Dalam kegiatan belajar mengajar di kelas terkadang seorang guru harus menghadapi siswa yang nakal dan mengalami kesulitan belajar. Mengenai hal tersebut ibu Maulidah Nur, Selaku guru PAI mengatakan;

"Upaya yang kami lakukan agar siswa memiliki motivasi, minat dan sikap yang kita harapkan, kami membiasakan anak yang melanggar tata tertib kelas pada saat kegiatan pembelajaran dengan cara membaca dan menulis materi yang saya

11 Observasi, Tentang Fasilitas Mengajar, Tanggal 13 April 2018.

12 Badrus Syamsih, Wali Kelas VII SMP Al-Faqih Sumber Nyamplong Pamekasan, Wawancara Langsung, Tanggal 10 Oktober 2018.

13 Observasi, Tentang Pemberian Motivasi Kepada Siswa, Tanggal 16 Oktober 2018,

14 Zainullah, Wali Kelas IX SMP Al-Faqih Sumber Nyamplong Pamekasan, Wawancara Langsung, Tanggal 16 Oktober 2018. 
bahas, selain itu saya disiplin menerapkan sistem menghafal pokok-pokok materi seperti halnya contoh-contoh akhlak terpuji dan akhlak tidak terpuji, menghafal bacaan dalam mensalati mayit maupun niat dalam tayammum."

Kedisiplinan dan sikap pembiasaan perlu ditanamkan pada siswa agar terbiasa memiliki tanggung jawab baik kepada dirinya maupun kepada orang lain. Siswa sekolah menengah merupakan masa transisi antara dunia anak-anak dan dewasa sehingga sering timbul goncangan dan gejolak dalam dirinya. Disamping itu, mereka mudah terpengaruh dengan lingkungan sekitar, dalam hal ini, guru berperan penting untuk mengatasi kurangnya siswa dalam disiplin dengan diberlakukan cara seperti, menghafalkan pokok-pokok materi juga melakukan tanya jawab pada siswa saat kegiatan belajar mengajar sedang berlangsung. Sebagaimana yang diungkapkan oleh Anisatul Mardiyah;

"Pada bidang studi PAI penerapan sikap disiplin/pembiasaan kepada siswa seperti dalam menghafal tentang bacaan dalam menshalati mayit, niat tayammum, niat shalat jamak, selain itu memahami pokok-pokok bahasan merupakan sesuatu yang harus mendapatkan perhatian khusus agar siswa mampu menjawab pertanyaan dalam ulangan harian dan tugas-tugas, oleh sebab itu dalam proses pembelajaran kami membiasakan siswa untuk menghafal agar mudah dan mampu menjawab pertanyaan-pertanyaan dalam ulangan harian atau tugas dengan baik." 16

Berdasarkan hasil pengamatan yang dilakukan guru SMP Al-Faqih Sumber Nyamplong Kowel Pamekasan melakukan upaya-upaya untuk meningkatkan prestasi belajar siswa khususnya bagi siswa yang mengalami kesulitan belajar sehingga dengan mudah mengatasi kesulitan belajar siswa dan mampu memiliki motivasi, semangat dan keinginan untuk belajar sebagaimana yang telah disebutkan diatas. Hal ini dapat dilihat dalam proses pembelajaran yang dilakukan. Diantaranya yaitu guru memahami karakteristik peserta didik, khususnya bagi siswa yang mengalami kesulitan belajar, sehingga strategi yang digunakanpun sesuai dengan kondisi. ${ }^{17}$

\section{Hasil Pengelolaan Pembelajaran di SMP Al-Faqih Sumber Nyamplong Kowel Pamekasan}

Dengan diterapkannya pengelolaan pembelajaran yang tepat sasaran, maka kegiatan pembelajaran terlaksana dengan efektif, sebagaimana hasil kutipan wawancara berikut ini;

"Dengan diterapkannya pengelolaan pembelajaran di kelas, maka kegiatan pembejaran lebih atraktif, seperti siswa siswa tidak pasif dalam kegiatan pembelajaran dan kegiatan pembelajaran lebih efektif seperti kegiatan pembelajaran tidak monoton, sehingga kegiatan pembelajaran lebih kreatif dan menyenangkan." 18

15 Maulidah Nur, Guru PAI SMP Al-Faqih Sumber Nyamplong Pamekasan, Wawancara Langsung, Tanggal 16 Oktober 2018.

16 Anisatul Mardiyah, Siswa Kelas VIII SMP Al-Faqih Sumber Nyamplong Pamekasan, Wawancara Langsung, Tanggal 16 Oktober 2018.

17 Observasi, Tentang Upaya dalam Mengatasi Kesulitan Belajar Siswa anggal 18 Oktober 2018.

18 Muhammad Musleh Suaidi, Kepala SMP Al-Faqih Sumber Nyamplong Pamekasan, Wawancara Langsung, Tanggal 16 Oktober 2018. 
Apa yang disampaikan kepala sekolah di atas, senada dengan apa yang disampaikan oleh siswa kelas IX berikut ini;

"Kegiatan pembelajaran lebih menyenangkan, sehingga menambah motivasi siswa untuk aktif belajar di kelas, dikarenakan guru lebih kreatif dalam mengajar, seperti guru menggunakan metode yang berbeda apalagi ketika didukung dengan menggunakan media pembelajaran, siswa lebih antusias untuk belajar. ${ }^{19}$

Dalam kegiatan pembelajaran siswa dapat memahami bahan kajian atau materi pelajaran yang diberikan oleh guru, karena materi yang diberikan terlebih dahulu sudah dipelajari oleh siswa di rumah, sebagaimana yang diungkapkan oleh Bapak Muhammad Musleh Suaidi selaku Kepala Sekolah di SMP Al-Fqih, berikut ini kutipan wawancaranya;

"Saat ini alhamdulillah cara belajar anak-anak (siswa) sudah ada peningkatan dari pada sebelumnya, hal tersebut terbukti siswa mampu menjawab pertanyaanpertanyaan yang diberikan oleh guru baik sebelum dan sesudah kegiatan belajar mengajar. Hal itu biasa dilakukan oleh dewan guru agar siswa lebih siap dengan materi yang sudah dan yang akan dipelajarinya dan secara tidak langsung siswa akan mempelajari materi pelajaran yang akan dipelajari selanjutnya." 20

Apa yang disampaikan oleh kepala sekolah di atas ibu Lilik Halilah selaku wali kelas VIII menambahkan;

"Sebenarnya siswa itu ibaratnya rumput jika rumput tersebut kita siram dan kita rawat maka rumput tersebut akan menjadi rumput yang baik, akan tetapi juga sebaliknya bak. Nah begitu juga siswa, jika kita sabar dan tekun mengarahkan dan membimbingnya maka kita akan menghasilkan siswa yang baik, alhamdulillah siswa di lembaga ini pada saat ini sebagian besar siswa memahami materi yang sudah diberikan atau dijelaskan hal tersebut terbukti ketika saya mengadakan tanya jawab kembali mengenai materi yang baru saja saya sampaikan sebagian besar siswa bisa menjawabnya." 21

Berdasarkan hasil observasi yang dilakukan oleh peneliti mengenai pelaksanaan belajar mengajar di SMP Al-Faqih, guru memberikan kesempatan kepada siswa untuk bertanya dan siswa yang lain untuk menjawab dan setelah itu siswa diberikan kesempatan menyimpulkan hasil kegiatan pembelajaran yang dilaksanakan dan satu persatu siswa mencoba memberikan kesimpulan dan pada akhirnya guru lebih memperjelas hasil kesimpulan dari siswanya, dengan rasa senang guru menutup kegiatan pembelajaran karena tujuan dari kegiatan pembelajaran telah dicapai oleh siswa. $^{22}$

Pada kesempatan yang lain, peneliti mencari informasi tentang kemampuan siswa dalam mendalami materi pelajaran sehingga siswa mampu mendeskripsikan

19 Rofi'i, Siswa Kelas IX SMP Al-Faqih Sumber Nyamplong Pamekasan, Wawancara Langsung, Tanggal 16 Oktober 2018.

20 Muhammad Musleh Suaidi, Kepala SMP Al-Faqih Sumber Nyamplong Pamekasan, Wawancara Langsung, Tanggal 16 Oktober 2018.

21 Lilik Halilah, Wali Kelas VIII SMP Al-Faqih Sumber Nyamplong Pamekasan, Wawancara Langsung, Tanggal 16 Oktober 2018.

22 Observasi Tentang Pelaksanaan Kegiatan Pembelajaran, Tanggal 20 Oktober 2018. 
atau menjelaskan materi yang telah disampaikan. Mengenai hal tersebut bapak Badrus Syamsih selaku Wali Kelas VII mengatakan;

Syukur Alhamdulillah, usaha yang selama ini kami lakukan mendapatkan hasil yang lumayan bagus, dimana sebagian siswa sudah bisa menganalisis atau menjelaskan ulang materi yang baru saja disampaikan, yang tentunya hal tersebut membutuhkan ketekunan siswa dalam memahami materi pelajaran. ${ }^{23}$

Sedangkan pengamatan yang dilakukan oleh peneliti mengenai sikap antusiasme siswa pada saat pelaksanaan kegiatan belajar mengajar di SMP Al-Faqih siswa memiliki antusiasme yang tinggi ketika guru kelas melaksanakan kegiatan belajar mengajar siswa mampu memberikan sanggahan bahkan memberikan kesimpulan terhadap materi yang disampaikan meskipun hal itu kurang sempurna yang pada akhirnya guru lebih menyempurnakan kesimpulan hasil pembelajaran. ${ }^{24}$

Sedangkan mengenai nilai hasil belajar siswa dapat dikatakan lebih baik dari tahun-tahun sebelumnya, baik itu nilai tugas secara individu, ulangan harian maupun nilai tes pada saat setelah kegiatan pembelajaran yang biasanya digunakan oleh guru untuk mengetahui tingkat ketercapaian terhadap tujuan pembelajaran, sebagaimana yang diungkapkan oleh bapak Zainullah;

"Jika dibandingkan dengan tahun-tahun sebelumnya prestasi belajar siswa bisa dibilang lebih baik, hal tersebut semakin meningkatnya nilai siswa pada nilai tugas individu maupun kelompok dan nilai-nilai ulangan harian yang telah dilaksanakan." 25

Hal tersebut diperkuat oleh pendapat bapak Rofi'i berikut ini;

"Menurut hemat saya, guru di lembaga ini sudah mengalami peningkatan dari tahun ketahun dan mampu memberikan kepercayaan lebih kepada masyarakat dan orang tua salah satunya adalah prestasi akademik yang selalu meraih presatasi yang bagus akan tetapi hanya di tingkat Kecamatan, namun kami belum mencapai prestasi yang memuaskan apabila terdapat ajang lomba tingkat Kabupaten apalagi tingkat Jawa Timur, seperti olimpiade Sains dan Matematika, kami hanya mampu menjadi juara III olimpiade tingkat Kabupaten. Begitu juga prestasi non akademik di tingkat kecamatan kami selalu eksis menjadi juara, seperti lomba tartil Qur'an, puisi, tenis meja."26

Mengenai perkembangan minat dan motivasi belajar siswa, peneliti mengadakan wawancara dengan kepala sekolah berikut ini kutipan wawancaranya;

"Menurut saya, guru di lembaga ini sudah menerapkan beberapa strategi mengajar agar siswa memiliki minat dan motivasi belajar tidak hanya di kelas tetapi juga di rumah dengan cara selalu memberikan tugas PR, ulangan harian, hafalan surat-surat pendek dan mengumpulkan materi-materi yang ada kaitannya dengan materi yang akan disampaikan selanjutnya dan semuanya itu terlaksana sesuai harapan meskipun ada beberapa orang siswa yang masih mengalami

23 Badrus Syamsih, Wali Kelas VII SMP Al-Faqih Sumber Nyamplong Pamekasan, Wawancara Langsung, Tanggal 20 Oktober 2018.

24 Observasi, Tentang Suasana Kelas dalam Kegiatan Belajar Mengajar, Tanggal 20 Oktober 2018.

25 Zainullah, Wali Kelas IX SMP Al-Faqih Sumber Nyamplong Pamekasan, Wawancara Langsung, Tanggal 16 Oktober 2018.

26 Rofi'i, Siswa Kelas IX SMP Al-Faqih Sumber Nyamplong Pamekasan, Wawancara Langsung, Tanggal 24 Oktober 2018.. 
beberapa kesulitan belajar akan tetapi secara keseluruhan siswa memiliki minat dan motivasi untuk belajar, meskipun reward yang diperoleh hanya berupa nilai sesuai kemampuannya, namun hal itu harus tetap dipertahankan agar lembaga terus mendapat respon positif dari masyarakat."27

\section{Faktor Pendukung dan Penghambat Pengelolaan Pembelajaran di SMP Al- Faqih Sumber Nyamplong Kowel Pamekasan}

Temuan faktor pendukung pengelolaan pembelajaran di SMP Al-Faqih Sumber Nyamplong Kowel Pamekasan

Kegiatan beajar mengajar yang efektif dan efisien merupakan suatu kegiatan belajar yang berpusat pada siswa (siswa aktif) dan mengarah pada hasil yang dicapai sesuai dengan harapan, hal tersebut juga sebagaimana yang disampaikan oleh kepala sekolah SMP Al-Faqih berikut ini;

"Kegiatan belajar mengajar dapat dikatakan efektif, apabila tujuan pembelajaran yang diharapkan oleh guru dapat dicapai oleh siswa. Sedangkan menyenangkan sejauhmana guru menggunakan strategi-strategi yang dianggap sesuai dengan situasi dan kondisi lembaga dapat diterima oleh siswa dengan baik, sehingga kegiatan pembelajaran tidak bersifat penekanan kepada siswa, akan tetapi sebaliknya siswa lebih termotivasi untuk belajar." 28

Hal senada sebagaimana yang disampaikan oleh siswa keelas IX berikut ini;

"Kegiatan belajar lebih menyenangkan ketika guru menggunakan strategi yang berbeda dalam mengajar, artinya ketika materi pelajaran membutuhkan suatu praktek untuk dilaksanakan, maka guru menggunakan kesempatan tersebut untuk melaksanakan kegiatan praktek sesuai dengan materi dan lokasinya, sehingga menambah motivasi siswa untuk aktif dalam belajar." 29

Berdasarkan hasil observasi yang dilakukan oleh peneliti, ketika guru agama memberikan materi tentang praktek shalat janazah, guru dan siswa melaksanakan kegiatan belajar mengajarnya di masjid atau musala yang ada di lembaga tersebut, sehingga lebih leluasa bagi guru dan siswa dalam bereksplorasi. ${ }^{30}$

Mengenai perkembangan minat dan motivasi belajar siswa, peneliti mengadakan wawancara dengan ibu Lilik Halilah, beliau mengatakan;

"Kami selaku guru di lembaga ini sudah berusaha menerapkan beberapa strategi mengajar agar siswa memiliki minat dan motivasi belajar tidak hanya di kelas tetapi juga di rumah dengan cara selalu memberikan tugas PR, ulangan harian, hafalan surat-surat pendek dan mengumpulkan materi-materi yang ada kaitannya dengan materi yang akan disampaikan selanjutnya dan semuanya itu terlaksana sesuai harapan meskipun ada beberapa orang siswa yang masih mengalami beberapa kesulitan belajar akan tetapi secara keseluruhan siswa memiliki minat dan motivasi untuk belajar, meskipun reward yang diperoleh hanya berupa nilai

27 Muhammad Musleh Suaidi, Kepala SMP Al-Faqih Sumber Nyamplong Pamekasan, Wawancara Langsung, Tanggal 24 Oktober 2018.

28 Muhammad Musleh Suaidi, Kepala SMP Al-Faqih Sumber Nyamplong Pamekasan, Wawancara Langsung, Tanggal 27 Oktober 2018.

29 Rofi'i, Siswa Kelas IX SMP Al-Faqih Sumber Nyamplong Pamekasan, Wawancara Langsung, Tanggal 27 Oktober 2018.

30 Observasi, Tentang Praktek Shalat Janazah, Tanggal 13 Oktober 2018. 
sesuai kemampuannya, namun hal itu harus tetap dipertahankan agar lembaga terus mendapat respon positif dari masyarakat." 31

Apa yang disampaikan oleh ibu Lilik Halilah di atas, ditambahkan pula oleh bapak Badrus Syamsih, berikut ini kutipan wawancaranya;

"Salah satu bentuk bahwa siswa di lembaga ini memiliki motivasi belajar adalah dengan mengikuti kegiatan belajar mengajar dengan rasa senang, aktif pada kegiatan pembelajaran di kelas dan juga aktif dalam mengerjakan tugas-tugas yang diberikan." 32

Proses belajar mengajar merupakan satu kesatuan yang utuh dan tidak dapat dipisahkan antara pendidik dan peserta didik. Guru merupakan sebuah profesi yang membutuhkan keahlian khusus sebagai tenaga yang profesional. Untuk itu kepala SMP Al-Faqih untuk menghasilkan tenaga pendidik yang profesional, kepala sekolah membantu dan memberikan kesempatan serta peluang kepada guru agar dapat menambah kemampuan sesuai profesi yang ditekuninya, seperti mengirim guru pada berbagai diklat profesi keguruan, workshop dan penataran, seperti Kelompok Kerja Guru (KKG) atau Musyawarah Guru Mata Pelajaran (MGMP) sebagaimana yang diungkapkan oleh kepala SMP Al-Faqih berikut ini;

"Saya sering mengirimkan teman-teman guru dalam kegiatan pendidikan dan latihan (DIKLAT) serta workshop tentang pendidikan seperti Kelompok Kerja Guru (KKG) atau Musyawarah Guru Mata Pelajaran (MGMP) juga diklat tentang kurikulum dan baru-baru ini saya telah mengutus 5 orang guru untuk diseleksi mengikuti diklat guru sertifikasi, namun yang terjaring hanya 1 orang meskipun seperti itu kami tetap optimis untuk tetap mengirimkan teman-teman ke berbagai diklat yang diselenggarakan oleh pemerintah maupun instansiinstansi lainnya, agar teman-teman mampu menyesuaikan diri dengan perkembangan profesi tenaga kependidikan yang akhir-akhir ini menuntut menjadi guru yang profesional.",33

Upaya yang dilakukan oleh seorang guru dalam kegiatan belajar mengajar di kelas adalah mampu mengelola proses belajar mengajar dengan menguasai bahan pelajaran sebelum mengajar di kelas, memiliki wawasan keilmuwan yang relevan dengan bidang studi yang dipegangnya, mampu menciptakan lingkungan belajar yang efektif dan menyenangkan serta menggunakan metode yang sesuai dengan karakteristik siswanya sehingga siswa faham dan tidak mengalami kesulitan belajar. Sebagaimana pernyataan kepala sekolah SMP Al-Faqih, berikut ini kutipan wawancaranya;

"Ketika guru melaksanakan kegiatan belajar mengajar, dia sudah memiliki RPP dan silabus serta mengerti cara mengelola pembelajaran sehingga akan terus berusaha dan berusaha agar anak didik faham dan tidak mengalami kesulitan belajar, berusaha disini dalam arti mencari strategi pembelajaran yang baik bagi mereka, karena terkadang siswa yang satu dengan yang lainnya ini tingkat

31 Lilik Halilah, Wali Kelas VIII SMP Al-Faqih Sumber Nyamplong Pamekasan, Wawancara Langsung, Tanggal 30 Oktober 2018.

32 Badrus Syamsih, Wali Kelas VII SMP Al-Faqih Sumber Nyamplong Pamekasan, Wawancara Langsung, Tanggal 30 Oktober 2018.

33 Muhammad Musleh Suaidi, Kepala SMP Al-Faqih Sumber Nyamplong Pamekasan, Wawancara Langsung, Tanggal 30 Oktober 2018. 
pemahaman, motivasi belajar dan keinginan untuk belajar sangat berbeda untuk itu saya harus menguasai materi pelajaran agar saya bisa mengelola kegiatan pembelajaran." 34

Sedangkan faktor penghambat pengelolaan pembelajaran di SMP Al-Faqih Sumber Nyamplong Kowel Pamekasan, berikut ini hasil temuannya;

Guru SMP Al-Faqih paham bahwa untuk meraih suatu keberhasilan proses pembelajaran sangat ditentukan oleh beberapa komponen. Komponen tersebut dapat berasal dari guru, siswa, sarana prasarana, kurikulum, orang tua, dan lain-lain. Komponen-komponen ini akan saling berkaitan antara yang satu dengan yang lain. Adapun yang paling terasa bagi guru dalam melakukan pengelolaan kegiatan pembelajaran adalah lingkungan sekolah yang berada di lingkungan pondok, sehingga mengurangi guru dalam merancang kegiatan belajar yang efektif, sebagaimana yang disampaikan kepala sekolah berikut ini;

"Terbatasnya ruang gerak guru dan siswa dalam mengeksplorasi kemampuan dan keinginan terhadap kegiatan pembelajaran yang kreatif dan menyenangkan, patut dimaklumi, karena lembaga ini berada dibawah naungan pondok pesantren, sehingga perilaku-perilaku belajar yang kreatif dan menyenangkan dibutuhkan penyesuaian yang tidak melanggar aturan-aturan dan tata tertib pondok pesantren." 35

Sedangkan berdasarkan hasil observasi, guru di SMP Al-Faqih kurang leluasa dalam melaksanakan kegiatan belajar mengajar yang kreatif dan menyenangkan, karena terkendala oleh aturan-aturan pondok yang tidak memperbolehkan siswa dan siswa berbicara, sehingga mengurangi keaktifan pengelolaan pembelajaran di kelas. ${ }^{36}$

Selain itu faktor sarana dan prasarana merupakan faktor terpenting dalam kegiatan pendidikan. Tanpa sarana dan prasaran yang memadai atau setidaknya berkecukupan maka akan sulit bagi sekolah untuk memajukan lembaga pendidikan tersebut, karena semua kegiatan tidak akan berjalan dengan lancar dan sering menghadapi kendala, mengenai hal tersebut berikut hasil wawancaranya;

"Lembaga kami berusaha terus membenahi dan melengkapi sesuai dengan anggaran dan rencana pengembangan setiap tahunnya dan bantuan dari pihak luar seperti pemerintah dan masyarakat. Sarana dan prasarana dapat dikatakan masih kurang mendukung khususnya prasarana pada bidang ektrakurikuler yang bisa dikatakan minim sekali.",37

Berdasarkan hasil pengamatan, sarana dan prasarana pada bidang ektrakurikuler dikatakan sangat minim seperti sarana olah raga yang seadanya, lapangan tennis meja yang malai rusak, tidak memiliki gudang tempat menyimpan barang-barang yang sudah rusak dan yang lainnya. ${ }^{38}$

34 Muhammad Musleh Suaidi, Kepala SMP Al-Faqih Sumber Nyamplong Pamekasan, Wawancara Langsung, Tanggal 02 November 2018.

35 Muhammad Musleh Suaidi, Kepala Sekolah SMP Al-Faqih Sumber Nyamplong Pamekasan, Wawancara Langsung, Tanggal 02 November 2018.

36 Observasi, Tentang Tatatertib Pondok Pesantren, Tamnggal 02 November 2018

37 Muhammad Musleh Suaidi, Kepala Sekolah SMP Al-Faqih Sumber Nyamplong Pamekasan, Wawancara Langsung, Tanggal 04 November 2018.

38 Observasi, Tentang Sarana Prasarana, Tanggal 04 November 2018. 


\section{Pembahasan}

Pada bagian ini, Peneliti akan menganalisa data sesuai dengan di lapangan yang dihubungkan dengan teori yang ada yaitu sebagai berikut:

\section{Pengelolaan Pembelajaran di SMP Al-Faqih Sumber Nyamplong Kowel Pamekasan}

Agar siswa dapat berperan secara aktif dalam proses belajar mengajar, maka guru harus dapat mengelola, menyediakan atau menciptakan suatu kondisi pembelajaran siswa secara terencana dan baik. Menurut Dimyati dan Mudjiono klasifikasi strategi pengelolaan belajar mengajar adalah sebagai berikut: ${ }^{39}$ Pertama pengaturan guru-siswa Dari segi pengaturan guru, pembelajaran dapat dilakukan oleh guru secara perorangan dan dapat pula dilakukan oleh suatu team (team teaching). Di samping itu, pembelajaran juga dapat dilakukan secara tatap muka atau dengan menggunakan perantara media. Sedangkan dari segi pengaturan murid, dapat dibedakan atas pembelajaran klasikal (kelompok besar), kelompok kecil dan pembelajaran individual. Kedua guru dan murid dalam pengolahan pesan. Kegiatan pembelajaran dapat dilakukan dalam keadaan siap, artinya pesan diolah oleh guru secara tuntas sebelum disampaikan disebut pembelajaran bersifat ekspositorik, sedangkan pembelajaran yang mengharuskan pengolahan pesan oleh siswa disebut dengan pembelajaran bersifat heuristik atau hipotetik. Ketiga proses pengolahan pesan. Peristiwa pembelajaran yang bertolak dari yang umum untuk dilihat keberlakuannya atau akibatnya pada yang khusus disebut strategi yang bersifat deduktif, sedangkan yang ditandai oleh proses berpikir yang bergerak dari yang khusus ke umum, disebut dengan strategi induktif. Keempat tujuan belajar. Tujuan belajar ini merupakan suatu pernyataan yang spesifik yang dinyatakan dalam perilaku atau penampilan yang diwujudkan dalam bentuk tulisan untuk menggambarkan hasil yang diharapkan.

Ada lima macam tujuan yang membutuhkan sistem lingkungan belajar, yaitu : Pertama tingkat pengetahuan, kemampuan seseorang dalam menghafal atau mengingat pengetahuan yang pernah diterimanya. Kedua tingkat pemahaman, kemampuan seseorang dalam mengartikan menafsir, menerjemah dengan menggunakan cara sendiri. Ketiga tingkat penerapan, kemampuan seseorang dalam menggunakan pengetahuan dan wawasan yang dimilikinya untuk memecahkan masalah. Keempat tingkat analisis, kemampuan seseorang dalam menggunakan pengetahuan dalam memecahkan masalah yang timbul dalam kehidupan sehari-hari. Kelima tingkat sintesis, kemampuan seseorang dalam mengaitkan dan menyatukan berbagai elemen dan unsur pengetahuan yang ada sehingga terbentuk pola baru yang lebih menyeluruh. ${ }^{40}$

Sedangkan berdasarkan hasil temuan penelitian mengenai pengelolaan pembelajaran dapat disimpulkan sebagai berikut: Pertama guru melakukan perencanaan terlebih dahulu dengan menetapkan sasaran tujuan pengajaran yang jelas dan konkret. Penetapan tujuan pengajaran oleh guru dibuat dengan jelas, karena dianggap sangat penting untuk disampaikan kepada siswa, sehingga dapat mempermudah siswa dalam memahami materi yang harus dikuasai. Selain itu

39 Dimyati dan Mudjiono, Belajar dan Pembelajaran (Jakarta: Renika Cipta, 2005), 169

40 Hamzah. B. Uno, Perencanaan Pembelajaran (Jakarta: Bumi Aksara, 2009), 36. 
kegiatan belajar mengajar akan lebih terarah sesuai dengan tujuan tersebut, seperti menetapkan dan membahas materi-materi pokok yang harus disampaikan kepada siswa dan mencatat hal-hal pokok sesuai dengan tujuan pembelajaran dengan begitu siswa lebih mudah dalam mencapai tujuan pengajaran.

Kedua guru melakukan pengorganisasian strategi belajar dengan menetapkan jenis metode, media, sumber belajar dan fasilitas belajar mengajar. Strategi pengorganisasian pembelajaran dilakukan oleh guru dengan lebih terstruktur, tertata rapi agar sesuai dengan harapan. Dalam kegiatan pengorganisasian pembelajaran tersebut guru berusaha menyesuaikan fasilitas atau sarana sekolah dengan materi pelajaran, guru menetapkan metode dan media yang sesuai dengan materi serta berupaya menyediakan sumber-sumber belajar yang dapat mendukung kegiatan pembelajaran yang efektif, seperti literature yang dapat menunjang penyampaian materi kepada peserta didik.

Ketiga, guru menetapkan waktu secara terperinci dan berusaha membimbing serta memberikan motivasi kepada siswa untuk aktif belajar. Dalam menentukan waktu kegiatan belajar mengajar yang efektif, guru tetap berpedoman pada kurikulum yang telah ditetapkan dan terperinci pada Rencana Program Pembelajaran (RPP), seperti 15 menit kegiatan awal, 60 menit kegiatan inti dan 15 menit kegiatan akhir. Selain menetapkan waktu dalam kegiatan belajar mengajar, juga berupaya memberikan dorongan dan motivasi kepada siswa untuk lebih aktif belajar agar Ketuntasan Kriteria Minimal (KKM) dapat dicapai oleh siswa disela-sela kegiatan pembelajaran sedang berlangsung.

Keempat, guru kreatif menerapkan sikap disiplin atau pembiasaan di kelas. Dalam penerapan sikap disiplin di kelas, siswa harus siap menerima sanksi dari guru seperti ketika terlambat masuk kelas dan dijumpai salah satu siswa yang berbicara sendiri pada saat kegiatan pembelajaran berlangsung, guru memberikan sanksi membaca dan menulis pelajaran itu kembali, agar menjadi bahan pelajaran bagi siswa untuk tidak melakukan tindakan-tindakan yang melanggar tata tertib kelas, sehingga siswa mendengarkan secara seksama apa yang disampaikan oleh guru.

Kelima, guru melakukan evaluasi terhadap kegiatan pembelajaran. Kegiatan evaluasi pelaksanaan pembelajaran dilakukan oleh guru untuk membandingkan kegiatan pembelajaran dengan kegiatan sebelumnya, sehingga memiliki solusi jika didapat hal-hal yang tidak diharapkan terjadi selama kegiatan pembelajaran berlangsung, seperti, siswa ramai pada saat kegiatan belajar berlangsung, siswa kurang paham dengan materi pelajaran, penggunaan metode pembelajaran yang kurang efektif dan terjadinya kesalahan teknis dan non teknis dengan penggunaan media yang digunakan seperti; (a) media rusak sebelum digunakan, (b) media (laptop, kumputer dan proyektor) error, (c) terjadinya pemadaman listrik, (e) ruang kelas kurang memadai.

Penentuan strategi pembelajaran tidak hanya dilakukan guru dalam pelaksanaan pembelajaran, akan tetapi juga dalam perencanaan pembelajaran. Strategi pada perencanaan ini mengacu pada memilih, menetapkan dan merumuskan komponen pembelajaran. Sedangkan pada kegiatan pelaksanaan mengacu pada aktualisasi 
berbagai gagasan yang telah dirancang dengan modifikasi untuk mengembangkan potensi siswa. $^{41}$

Menurut Joni yang dikutip oleh Anitah bahwa yang menjadi acuan utama dalam penentuan strategi pembelajaran adalah tercapainya tujuan pembelajaran. ${ }^{42}$ Oleh karena itu pelaksanaan kegiatan pembelajaran yang tidak berorientasi pada tujuan pembelajaran tidak dapat dikatagorikan sebagai strategi pembelajaran. Untuk dapat merancang dan melaksanakan strategi pengelolaan pembelajaran yang efektif, diperlukan pengelolaan secara terstruktur, baik dari segi tujuan yang diharapkan, jenis metode yang digunakan serta penggunaan media pembelajaran yang efektif dan efisien.

Pengolahan tersebut tidak hanya diarahkan kepada lingkup akademik, namun juga lingkup nonakademik dan perubahan perilaku. Dalam penelitainnya, Ali Nurhadi menyebutkan perubahan perilaku dapat diciptakan dalam pembelajran dengan cara menerapkan model pembelajaran PAKEM, memberikan motivasi terhadap tata tertib dan uswah atau teladan serta menerapkan strategi reward and punishment. $^{43}$

\section{Hasil Pengelolaan Pembelajaran di SMP Al-Faqih Sumber Nyamplong Kowel Pamekasan}

Seorang harus mampu memilih strategi yang dianggap cocok dengan situasi dan kondisi lingkungan. Oleh karena itu seorang guru perlu memahami prinsip-prinsip penggunaan strategi pengelolaan pembelajaran yaitu sebagai berikut: ${ }^{44}$ Pertama, berorientasi pada tujuan. Dalam sistem pembelajaran merupakan komponen utama aktivitas guru dan siswa. Untuk itu sudah seharusnya diupayakan untuk mencapai tujuan yang telah ditentukan. Oleh karena itu keberhasilan suatu pengelolaan pembelajaran dapat ditentukan dari keberhasilan siswa dalam mencapai tujuan pembelajaran. Kedua, aktivitas. Dalam kegiatan belajar adalah berbuat,memperoleh pengalaman tertentu sesuai denan tujuan yang diharapkan. Oleh karena itu pengelolaan pembelajaran harus dapat mendorong aktivitas siswa baik secara fisik maupun secara mental.

Ketiga, Individualitas. Mengajar adalah usaha mengembangkan setiap individu siswa, walaupun kita mengajar pada kelompok siswa, namun pada hakekatnya yang ingin kita capai adalah perubahan perilaku setiap siswa. Keempat, Integritas. Mengajar bukan hanya mengembangkan kemampuan aspek kognitif saja, akan tetapi juga meliputi pengembangan aspek afektif dan psikomotor. Oleh karena itu strategi pengelolaan pembelajaran harus dapat mengembangkan seluruh aspek keperibadian secara terintegrasi.

Sedangkan menurut Mulyasa karakteristik guru yang berhasil mengembangkan strategi pembelajaran diidentifikasi sebagai berikut: (a) respek dan memahami serta

41 Sri Anitah, strategi Pembelajaran (Jakarta: Universitas Terbuka, 2009), 124.

42 Ibid.

43 Ali Nurhadi dan Dedi Yusuf. MANAJEMEN PEMBELAJARAN BERBASIS PENDEKATAN PERUBAHAN PERILAKU DALAM MENINGKATKAN MOTIVASI BELAJAR SISWA DI SMP NEGERI 3 PADEMAWU PAMEKASAN. Jurnal re-JIEM (Research Journal of Islamic Management Education) Volume 2 Nomor 2. 2019. 288-304

44 Wina Sanjaya, Strategi Pembelajaran, Berorientasi Standar Proses Pendidikan (Jakarta; Prenada Media, 2006), 131. 
dapat mengontrol sikap dan emosinya, (b) antusias dan bergairah terhadap bahan, kelas dan seluruh kegiatan pembelajaran, (c) berbicara dengan jelas dan komunikatif, (d) memperhatikan perbedaan individual peserta didik, (e) memiliki banyak pengetahuan, inisiatif dan kreatif, (f) tidak menonjolkan diri menjadi teladan bagi peserta didik. $^{45}$

Lain halnya menurut Samiawan, bahwa guru yang kreatif dikelompokkan menjadi 3 kelompok yaitu sebagai berikut: ${ }^{46}$ (a) kemapuan umum. Pada kemampuan ini guru dapat mengintegrasikan pengalaman, kemampuan untuk memproses informasi yang menghasilkan respon untuk menyesuaikan diri secara adaptif dalam situasi baru serta kemampuan berpikir abstrak. (b) kemampuan dalam memiliki komitmen terhadap tugas. Pada kemampuan ini guru memiliki motifasi yang tinggi dalam melaksanakan tugas dan fungsinya sebagai pendidik, sehingga dengan memiliki motifasi dapat dijadikan pendorong oleh guru dalam melaksanakan tugastugasnya secara maksimal. (d) kreativitas menunjukkan pada dimensi-dimensi yang kreatif, seperti ketajaman dan kecerdasan yang konstruktif, fokus pada tujuan dan memiliki sikap tujuan serta kesadaran sosial.

Sedangkan berdasarkan hasil temuan penelitian mengenai hasil pengelolaan pembelajaran yaitu sebagai berikut:

Pertama, siswa lebih aktif dan kegiatan pembelajaran lebih menyenangkan. Dengan diterapkannya pengelolaan pembelajaran, maka kegiatan pembelajaran lebih atraktif, seperti siswa siswa tidak pasif dalam kegiatan pembelajaran dan kegiatan pembelajaran lebih efektif seperti kegiatan pembelajaran tidak monoton, karena guru lebih kreatif dalam mengajar, seperti penggunaan metode yang variatif dan didukung dengan penggunaan media pembelajaran, sehingga siswa lebih termotivasi untuk belajar.

Kedua, siswa mampu meningkatkan pengetahuannya terhadap materi yang sudah dan yang akan di sampaikan guru. Cara belajar siswa mangalami peningkatan dari pada sebelumnya, hal tersebut terbukti siswa mampu menjawab pertanyaanpertanyaan yang diberikan oleh guru baik sebelum dan sesudah kegiatan belajar mengajar. Kegiatan tersebut dilakukan oleh dewan guru agar siswa lebih siap dengan materi yang sudah dan yang akan dipelajarinya dan secara tidak langsung siswa akan mempelajari materi pelajaran yang akan dipelajari selanjutnya. Hal tersebut karena guru dalam mendidik siswa mengibaratkan siswa seperti rumput yang dirawat akan menjadi rumput yang baik dan bernilai seni, begitu juga sebaliknya. Oleh karena itu, guru lebih sabar dan tekun mengarahkan dan membimbing siswa agar menghasilkan siswa yang baik, seperti siswa memahami materi yang sudah dijelaskan yang dibuktikan ketika guru mengadakan tanya jawab mengenai materi yang dijelaskan dan sebagian besar siswa mampu menjawab dengan baik.

Ketiga, siswa mampu menganalisis materi yang sudah dijelaskan. Upaya yang telah dilakukan oleh guru dapat dikatakan mendapatkan hasil yang lumayan baik, karena sebagian siswa sudah bisa menganalisis atau menjelaskan ulang materi yang baru saja disampaikan, walaupun hal itu membutuhkan ketekunan siswa dalam memahami materi pelajaran. Strategi yang dilakukan oleh guru di lembaga tersebut

45 E. Mulyasa, Pengembangan dan Implementasi Kurikulum 201 (Bandung: Remaja Rosdakarya 2013), 44.

46 Conny R. Semiawan, Kreativitas Keberbakatan (Jakarta: Renika Cipta, 2015), 35. 
adalah dengan selalu menyampaikan hal-hal yang harus dipahami dan dicapai pada saat kegiatan belajar mengajar (tujuan pembelajaran) kepada siswa dengan cara selalu memberikan tanya jawab atau memberikan kesempatan kepada siswa untuk menjelaskan ulang atau menyimpulkan materi yang diberikan.

Keempat, siswa mampu meningkatkan prestasi akademik dan nonakademik. Prestasi siswa banyak mendapat raihan juara akan tetapi hanya ditingkat kecamatan, akan tetapi bulum berbicara banyak ditingkat kabupaten. Pada bidang akademik prestasi siswa diantaranya yaitu (1) juara III lomba Olimpiade tingkat Kabupaten, (2) juara II lomba Olimpiade tingkat Kecamatan, (3) juara I lomba Sain tingkat Kecamatan. Sedangkan prestasi siswa pada bidang nonakademik yaitu: (1) juara I lomba tartil Qur'an tingkat kecamatan, (2) delegasi lomba tenis meja tingkat kabupaten, (3) juara II lomba kalegrafi tingkat kecamatan, (4) juara I lomba puisi tingkat kecamatan, (5) juara III lomba bulu tangkis tingkat kecamatan.

Kelima, siswa memiliki minat dan motivasi untuk belajar. Guru telah menerapkan beberapa strategi pengelolaan mengajar agar siswa memiliki minat dan motivasi belajar tidak hanya di kelas tetapi juga di rumah dengan cara selalu memberikan tugas PR, ulangan harian, hafalan surat-surat pendek dan mengumpulkan materi-materi yang ada kaitannya dengan materi yang akan disampaikan selanjutnya dan semuanya itu terlaksana sesuai harapan meskipun ada beberapa orang siswa yang masih mengalami beberapa kesulitan belajar akan tetapi secara keseluruhan siswa memiliki minat dan motivasi untuk belajar, meskipun reward yang diperoleh hanya berupa nilai sesuai kemampuannya, namun hal itu harus tetap dipertahankan agar lembaga terus mendapat respon positif dari masyarakat.

\section{Faktor Pendukung dan Penghambat Pengelolaan Pembelajaran di SMP Al- Faqih Sumber Nyamplong Kowel Pamekasan}

Tujuan pembelajaran merupakan dasar pencapaian efektif tidaknya strategi yang digunakan oleh pendidik. Artinya tujuan pembelajaran merupakan salah satu faktor yang mempengaruhi keberhasilan belajar mengajar di kelas. Keberhasilan sistem pengajaran juga dipengaruhi oleh beberapa faktor seperti faktor guru, siswa, sarana prasarana dan lingkungan: ${ }^{47}$

Faktor guru. Guru merupakan komponen yang menentukan keberhasilan sistem pengajaran, hal ini disebabkan karenaguru merupakan orang yang secara langsung berhadapan secaralangsung dengan siswa. Dalam pengelolaan pembelajaran, guru berperan sebagai perencana (planer) atau desainer (desainer) pembelajaran. Sebagai perencana guru dituntut memahami secara benar kurikulum, karakteristik siswa, fasilitas dan sumber daya yang ada.

Guru sebagai tenaga edukatif dalam lingkup sekolah atau lembaga pendidikan mempunyai tuntutan untuk memiliki kecakapan-kecakapan dasar kependidikan. Sebab saat guru melakukan proses pembelajaran, guru harus memberi nuansa dan situasi yang hidup serta menyenangkan bagi peserta didik, dengan kompetensi itu

47 Wina Sanjaya, Perencanaan dan Desain Sistem Pembelajaran (Jakarta: Kencana Prenada, 2008), 17. 
diharapkan guru dapat menumbuhkan kualitas pengajaran dan pembelajaran yang semakin baik. ${ }^{48}$

Faktor siswa. Latar belakang siswa menutut perlakuan berbeda dalam menyesuaikan gaya belajar di kelas. Dalam kegiatan belajar mengajar di kelas pasti dijumpai beragaram karakter siswa seperti siswa aktif dan ada pula siswa yang pendiam serta siswa yang memiliki motivasi rendah, hal tersebut sangat mempengaruhi proses pengelolaan pembelajaran di kelas.

Faktor sarana prasarana. Sarana adalah segala sesuatu yang secara langsung mendukung proses pembelajaran seperti, media pembelajaran, alat-alat pelajaran, perlengakapan sekolah lainnya. Sedangkan prasarana adalah segala sesuatu yang secara tidak langsung menunjang keberhasilan proses pembelajaran seperti, ruang kelas, lingkungan, listrik dan lapangan olah raga. Kelengakapan sarana dan prasarana tersebut membantu guru dalam menyelenggarakan proses pembelajaran.

Faktor lingkungan. Faktor lingkungan ini meliputi situasi dan kondisi lembaga, masyarakat, iklim sosial dan psikologi komponen yang terlibat dalam kegiatan pembelajaran. Sekolah yang memiliki hubungan yang baik dengan lingkungan sekitar ditunjukkan adanya kerjasama antar guru, saling menghargai dan saling membantu, maka akan memungkinkan iklim belajar menjadi sejuk dan tenang, sehingga akan berdampak pada motivasi belajar siswa.

Pendapat tersebut juga sebagaimana yang disampaikan oleh Fuad Ihsan dalam bukunya Dasar-Dasar Kependidikan, bahwa dalam kegiatan belajar mengajar komponen yang berkaitan erat satu sama lain adalah guru dan siswa siswa. ${ }^{49}$

Peranan guru dalam proses KBM sangat sentral dan eksistensinya dipertanyakan secara fungsional, hal ini disebabkan oleh munculnya serangkaian fenomena para lulusan pendidikan yang secara moral cenderung merosot, secara intelektual akademik juga kurang siap untuk memasuki lapangan kerja, maka baik langsung maupun tidak langsung akan terkait dengan peranan guru sebagai pendidik profesional. Guru harus bisa memposisikan diri sebagai model atau sentral identifikasi diri dan konsultan bagi peserta didik, guru merupakan kunci utama di kelas karena besar pengaruhnya terhadap perilaku dan belajar para siswa yaitu, otoritas akademis dan nonakademis, kesahatan mental, moral, kesenangan, cita-cita dan sikap. ${ }^{50}$

Dalam pendidikan, peserta didik dipandang sebagai organisme yang pasif, hanya menerima informasi dari orang dewasa, kini dengan makin cepatnya perubahan sosial, dan berkat penemuan teknologi, maka komonikasi antar manusia berkembang amat cepat. Peserta didik dalam usia dan tingkat kelas yang sama bisa memiliki profil materi pengetahuan yang berbeda-beda, hal ini tergantung kepada konteks yang mendorong perkembangan siswa. Adapun konteks yang dapat mendorong siswa antara lain yaitu; 1) Lingkungan dimana peserta didik belajar, baik secara

${ }^{48}$ Mohammad Muchlis Solichin, Moh. Hafidz, dan Hilmi Qosim Mubah. KUALITAS PROGRAM PERSIAPAN GURU TUGAS DI PONDOK PESANTREN MAMBAUL ULUM BATA-BATA PANAAN PALENGAAN PAMEKASAN. Jurnal re-JIEM (Research Journal of Islamic Education Management. Volume Volume 2 Nomor 2 tahun 2019. 305-320.

49 Fuad Ihsan, Dasar-Dasar Kependidikan (Jakarta: PT. Renika Cipta, 2010), 9.

50 Muhaimin, Pengembangan Kurikulum Pendidikan Agama Islam (Jakarta: Raja Grafindo Persada, 2010), 52 
kebetulan maupun tidak siswa belajar tidak berprogram. 2) Lingkungan belajar, dimana peserta didik belajar secara sengaja dan dikehendaki. 3) Sekolah dimana peserta didik belajar mengikuti program yang ditetapkan. 4) Lingkungan pendidikan optimal, di sekolah yang ideal dimana peserta didik dapat melakukan cara belajar siswa aktif sekaligus menghayati dan mengimplisitkan nilai-nilai. ${ }^{51}$

\section{KESIMPULAN}

Dari pembahasan di atas, dapat disimpulkan bahwa, pengelolaan pembelajaran di SMP Al-Faqih Sumber Nyamplong Kowel Pamekasan yaitu; a) Guru melakukan perencanaan terlebih dahulu dengan menetapkan sasaran tujuan pengajaran yang jelas dan konkret, b) Guru melakukan pengorganisasian strategi belajar dengan menetapkan jenis metode, media, sumber belajar dan fasilitas belajar mengajar, c) Guru menetapkan waktu secara terperinci dan berusaha membimbing serta memberikan motivasi kepada siswa untuk aktif belajar, d) Guru melakukan evaluasi terhadap kegiatan pembelajaran, e) Guru kreatif menerapkan sikap disiplin atau pembiasaan di kelas.

Hasil pengelolaan pembelajaran di SMP Al-Faqih Sumber Nyamplong Kowel Pamekasan yaitu; a) Siswa lebih aktif dan kegiatan pembelajaran lebih menyenangkan, b) Siswa mampu meningkatkan pengetahuannya terhadap materi yang sudah dan yang akan di sampaikan guru, c) Siswa mampu menganalisis materi yang sudah dijelaskan, d) Siswa mampu meningkatkan prestasi akademik dan non akademik, e) Siswa memiliki minat dan motivasi untuk belajar.

Faktor pendukung dan faktor penghambat pengelolaan pembelajaran di SMP AlFaqih Sumber Nyamplong Kowel Pamekasan yaitu yaitu; a) Faktor pendukung pengelolaan pembelajaran di SMP Al-Faqih yaitu; 1) Kegiatan pembelajaran lebih efektif dan menyenangkan, 2) Siswa memiliki minat dan motivasi untuk belajar yang lebih baik, 3) Adanya diklat dan penataran bagi guru, 4) Guru menguasai bahan pelajaran dan menciptakan lingkungan belajar yang efektif. b) Faktor penghambat pengelolaan pembelajaran di SMP Al-Faqih yaitu; 1) Faktor lingkungan yang ada dibawah naungan pondok pesantren, 2) Minimnya sarana dan prasarana yang memadai.

Adapun saran yang kiranya dapat bermanfaat bagi pihak-pihak yang terkait atas hasil penelitian ini. Adapun saran-saran tersebut yaitu sebagai berikut: Kepala sekolah hendaknya melakukan kunjungan kelas pada saat guru sedang melaksanakan kegiatan belajar mengajar di kelas, agar kepala sekolah mengetahui tingkat kelemahan dan kelebihan guru dan faktor-faktor penunjangnya dalam menyampaikan materi kepada siswa.

Hendaknya guru sering melakukan upaya-upaya pengelolaan pembelajaran, sehingga mutu hasil belajar mengajar dapat meningkat baik dari segi prestasi maupun dari segi minat dan motivasi belajar siswa.

Hendaknya kepala sekolah memiliki alternatif lain dalam memperoleh anggaran dana, namun tidak memberatkan siswa, sehingga kepala sekolah dan lembaga memiliki dana talangan dalam melengkapi fasilitas dan sarana prasarana lembaga, sehingga nantinya dapat menunjang kegiatan belajar mengajar.

51 Fuad Ihsan, Dasar-Dasar Kependidikan (Jakarta: Renika Cipta, 2010), 9. 


\section{DAFTAR PUSTAKA}

Akdon. Manajemen Strategi untuk Manajemen Pendidikan, diterjemahkan dari Strategik Management For Educational Management. Bandung: Alfabeta, 2011.

Anggoro, Toha. Metode Penelitian. Jakarta: Universitas Terbuka, 2007.

Anitah, Sri. Strategi Pembelajaran. Jakarta: Universitas Terbuka, 2009.

B. Uno, Hamzah. Perencanaan Pembelajaran. Jakarta: Bumi Aksara, 2009.

Buna'i. Perencanaan Pembelajaran PAI. Surabaya: Pena Salsabila, 2015.

Daryanto. Administrasi Pendidikan. Jakarta: Renika Cipta, 2008.

Deni Darmawan dan Supriadi. Komunikasi Pembelajaran. Bandung: Remaja Rosdakarya 2013.

Faridah Nurmaliyah dan Sugeng Listyo Prabowo. Perencanaan Pembelajaran. Malang: UIN-MALIKI PRES, 2010.

Handoko, T. Hani. Manajemen. Yogyakarta: BPFE-Yogyakarta, 2003.

Hendra Harmi dan Kasful Anwar. Perencanaan Sistem Pembelajaran KTSP. Bandung: ALFABETA, 2011.

Ihsan , Fuad. Dasar-Dasar Kependidikan. Jakarta: Renika Cipta, 2010.

Karwate, Engkay. Jurnal Pen elitian Pendidikan, Pengaruh Kemampuan Manajerial Kepla Sekolah dan Faktor Yang Mempengaruhi Motivasi Kerja Terhadap Kinerja Guru SLB di Kabupaten Subang, Vol,02, No, 01, Tahun 2010.

Majid, Abdul. Belajar dan Pembelajaran. Bandung: Remaja Rosdakarya, 2014.

- Perencanaan Pembelajaran Mengembangkan Standar Kompetensi Guru. Bandung: RemajaRosdakarya, 2013.

Majid, Abdul. Strategi Pembelajaran. Bandung: Remaja Rosdakarya, 2014.

Moleong, Lexy. J. Metodologi Penelitian Kualiatatif. Bandung: Remaja Rosdakarya, 2008.

Mudjiono dan Dimyati. Belajar dan Pembelajaran. Jakarta: Renika Cipta, 2006.

Muhaimin. Pengembangan Kurikulum Pendidikan Agama Islam. Jakarta: Raja Grafindo Persada, 2010.

Mulyasa, E. Kurikulum Tingkat Satuan Pendidikan. Bandung: Remaja Rosdakarya, 2007.

Mulyasa, E. Pengembangan dan Implementasi Kurikulum. Bandung: Remaja Rosdakarya 2013.

Nurhadi, Ali dan Dedi Yusuf. MANAJEMEN PEMBELAJARAN BERBASIS PENDEKATAN PERUBAHAN PERILAKU DALAM MENINGKATKAN MOTIVASI BELAJAR SISWA DI SMP NEGERI 3 PADEMAWU PAMEKASAN. Jurnal re-JIEM (Research Journal of Islamic Management Education) Volume 2 Nomor 2. 2019.

Sanjaya, Wina. Strategi Pembelajaran, Berorientasi Standar Pendidikan. Jakarta: Prenada Media, 2011.

Sardiman. Interaksi dan Motivasi Belajar Mengajar. Jakarta: Rajagrafindo Persada, 2012.

Semiawan, Conny R. Kreativitas Keberbakatan. Jakarta: Renika Cipta, 2015.

Solichin, Mohammad Muchlis, Moh. Hafidz, dan Hilmi Qosim Mubah. KUALITAS PROGRAM PERSIAPAN GURU TUGAS DI PONDOK PESANTREN MAMBAUL ULUM BATA-BATA PANAAN PALENGAAN PAMEKASAN. 
Jurnal re-JIEM (Research Journal of Islamic Education Management. Volume Volume 2 Nomor 2, 2019.

Suprayekti. Interaksi Belajar Mengajar. Jakarta: Direktorat Jenderal Pendidikan Dasar dan Menengah, 2004.

Syah, Darwyn. Perencanaan Sistem Pengajaran Pendidikan Agama Islam. Jakarta: Gaung Persada, 2007.

Syah, Muhibbin. Psikologi Belajar. Jakarta: Renika Cipta, 2011.

Syah, Muhibbin. Psikologi Pendidikan dengan Pendekatan Baru. Bandung: Remaja Rosdakarya, 2002. 